\title{
Stability Indicating HPLC Method for the Simultaneous Quantification of Aspirin and Pravastatin in bulk and Tablets: Method Development and Validation
}

\author{
Ravi Varma Athota ${ }^{1 *}$, Shanmukha Kumar Jagarlapudi ${ }^{1}$, Mutta Reddy Singampalli ${ }^{2}$ \\ ${ }^{1}$ Department of Chemistry, K L University, Guntur, Andhrapradesh, India. \\ ${ }^{2}$ Department of Chemistry, Government College for Women, Guntur, Andhrapradesh, India.
}

\section{ARTICLE INFO}

Article history:

Received on: 09/12/2016

Accepted on: 07/01/2017

Available online: 30/03/2017

\section{Key words:}

Aspirin, Pravastatin, Stability

indicating, Simultaneous,

Analysis.

\begin{abstract}
The aim of the present study was to develop and validate a stability indicating HPLC method for the simultaneous determination of aspirin and pravastatin in bulk and pharmaceutical dosage forms. The chromatographic separation of aspirin, pravastatin and their degradation products was achieved on Phenomex C18 column with mixture of water, acetonitrile and acetic acid $(40: 59: 01, v / v / v)$ as mobile phase in an isocratic elution mode at a flow rate of $1.5 \mathrm{~mL} / \mathrm{min}$. The method exhibited linearity in the concentration range of 20.5 $61.5 \mu \mathrm{g} / \mathrm{mL}$ and $10-30 \mu \mathrm{g} / \mathrm{mL}$ for aspirin and pravastatin, respectively. The limits of detection and quantification were $0.204 \mu \mathrm{g} / \mathrm{mL}$ and $0.680 \mu \mathrm{g} / \mathrm{mL}$ for aspirin and $0.077 \mu \mathrm{g} / \mathrm{mL}$ and $0.256 \mu \mathrm{g} / \mathrm{mL}$ for pravastatin, respectively. The developed method was validated with respect to accuracy, precision, selectivity, specificity and robustness. All the parameters examined were within the acceptance limits. The stability-indicating power of the proposed method was proved by subjecting the drugs to hydrolytic (acid and base), oxidative, photolytic and dry heat stress conditions. The developed method was found to be suitable for routine analysis of aspirin and pravastatin simultaneous in the presence of its stress degradation products.
\end{abstract}

\section{INTRODUCTION}

Pravastatin, chemically known as (3R,5R)-7[(1S,2S,6S,8S,8aR) -6-hydroxy-2-methyl-8- [(2S)-2-methyl butanoyl] oxy-1,2,6,7,8,8a-hexahydronaphthalen-1-yl]-3,5dihydroxyheptanoic acid (Figure 1), is a synthetic lipid lowering agent (Akira, 2010). Pravastatin lowers cholesterol synthesis by acting as an inhibitor of hydroxymethylglutaryl-CoA reductase enzyme. Pravastatin is used for lowering plasma cholesterol levels and prevention of cardiovascular disease (Nakamura et al., 2006; Toshio et al., 2009). Literature survey reveals that pravastatin is official in British Pharmacopoeia (British Pharmacopoeia, 2007a). Several analytical methods are available for the estimation of pravastatin in bulk, pharmaceutical

* Corresponding Author

Ravi Varma Athota, Department of Chemistry, KL University, Guntur, Andhrapradesh, India.Email: ravivarma.athota@gmail.com dosage forms and biological matrices, these include UV spectrophotometry (Balaji and Suman, 2009; Kunjan et al., 2014), visible spectrophotometry (Kalvikkarasi et al., 2009; Safwan and Mouhammed, 2011), HPLC (Bauer et al., 2005; Önal and Sagirli, 2006; Brain-Isasi et al., 2008; Safwan et al., 2008; Raj et al., 2010; Jane and Janivishal, 2013; Vania, 2014), LC-MS (Mulvana et al., 2000; Zhu and Neirinck, 2003; Kawabata et al., 2005; Sampath et al., 2011), capillary electrophoresis (Kircali et al., 2004; Nigovic and Vegar, 2008) and voltammetry (Nigović, 2006).<smiles>CC[C@H](C)C(=O)O[C@H]1C[C@@H](O)C=C2C=C[C@H](C)[C@H](CC[C@H](O)C[C@@H](O)CC(=O)O)[C@H]21</smiles>

Fig. 1: Structure of pravastatin. 
Aspirin, chemically known as 2-acetyloxybenzoic acid (Figure 2), is a nonsteroidal anti-inflammatory drug used in the temporary relief of various forms of pain and inflammation associated with various conditions (Valentin and Joseph, 2011). Aspirin is also commonly known as acetylsalicylic acid. Aspirin shows antipyretic, antirheumatic, analgesic and anticoagulant properties. Aspirin inhibits the biosynthesis of prostaglandins by inhibiting the activity of cyclooxygenase (Rod, 2003). Aspirin also prevents arterial and venous thrombosis by inhibiting platelet aggregation (Enma et al., 2012).

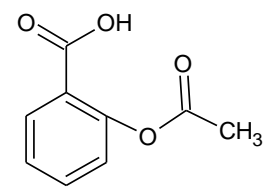

Fig. 2: Structure of aspirin.

Aspirin is official in United States Pharmacopoeia (United States Pharmacopoeia, 2000), British Pharmacopoeia (British Pharmacopoeia, 2007b) and Indian Pharmacopoeia (The Indian Pharmacopoeia, 2007). Different methods have been cited in the literature for determination of aspirin involving UV spectrophotometry (Lei, 2014), visible spectrophotometry (Maruf et al., 2001; Sahar, 2013), kinetic spectrophotometry (Senzana et al., 2008), FT-IR spectrophotometry (Andrei et al., 2006), surfaceenhanced raman scattering spectroscopy (Sallum et al., 2014), fluorescence spectroscopy (Moreira et al., 2004), HPLC (Kokot and Burda, 1998; Kumar et al., 2010; Ramjith et al., 2013), LCMS (Bae et al., 2008; Xu et al., 2009), potentiometry (Fernandes et al., 1998), differential scanning calorimetry (Luigi et al., 2010), voltametry (Majdi et al., 2007; Sartori et al., 2009; Codruţa and Ciprian, 2011) and capillary electrophoresis (Sekar et al., 2003). The aspirin and pravastatin combination is used to treat high cholesterol, lower the risk of stroke and heart attack in people with coronary heart disease (Charles et al., 2004). So far only liquid chromatography-tandem mass spectrometric (LC-MS/MS) assay method has been developed for the simultaneous quantification of pravastatin and aspirin using furosemide as internal standard in human plasma (Srinivasarao et al., 2012). The analytes and internal standard samples were chromatographed on a Zorbax SBC18 column by using a mixture of $5 \mathrm{mM}$ ammonium acetate buffer and acetonitrile $(20: 80, v / v)$ as the mobile phase at a flow rate of $0.8 \mathrm{~mL} / \mathrm{min}$. To the best of our knowledge, no reports could be found for the simultaneous determination of aspirin and pravastatin using HPLC with photodiode-array (PDA) detector. The present investigation describes the development of a stability indicating HPLC method applicable for the routine quality control analysis of aspirin and pravastatin simultaneously in their pure and tablets dosage forms.

\section{EXPERIMENTAL}

\section{Chemicals and solvents}

HPLC grade acetonitrile was purchased from Merck Pvt Ltd., Mumbai, India. Analytical reagent grade glacial acetic acid, hydrochloric acid, sodium hydroxide and hydrogen peroxide were obtained from Sd Fine Chemicals Ltd., Mumbai, India. Purified water was obtained from Milli-Q system. Aspirin and pravastatin were kindly provided by Lara Drugs Private Limited (Telangana, India). Pravigard tablets labeled to contain $81 \mathrm{mg}$ and $40 \mathrm{mg}$ of aspirin and pravastatin, respectively are manufactured by BristolMyers squibb company, Princeton, New Jersey.

\section{Instrumentation and chromatographic conditions}

The Waters HPLC system, consisted of a binary HPLC pump model 2695, PDA detector model 2998 and a vacuum degasser, all controlled by a Waters Empower 2 software, was used. HPLC analysis was performed isocratically at $25{ }^{\circ} \mathrm{C}$ temperature using a Phenomex C18 $(200 \mathrm{~mm} \times 4.6 \mathrm{~mm}, 5 \mu \mathrm{m})$ column. The mobile phase consisted of a mixture of water, acetonitrile and acetic acid (40:59:01, $v / v / v)$. The flow rate was 1.5 $\mathrm{mL} / \mathrm{min}$ and injection volume was $20 \mu \mathrm{L}$. The eluent was monitored with a detector set at $260 \mathrm{~nm}$.

\section{General procedure}

Stock standard solution of aspirin and pravastatin was prepared with mobile phase at a concentration of $410 \mu \mathrm{g} / \mathrm{mL}$ and $200 \mu \mathrm{g} / \mathrm{mL}$, respectively. Stock solution was kept refrigerated at $4{ }^{\circ} \mathrm{C}$ until further use. For the construction of calibration curves, serial portions of the stock solution were separately transferred into 5 sets of $10 \mathrm{~mL}$ volumetric flasks to produce working standard solutions of concentrations $20.50 \mu \mathrm{g} / \mathrm{mL}, 30.75 \mu \mathrm{g} / \mathrm{mL}$, $41.0 \mu \mathrm{g} / \mathrm{mL}, 51.25 \mu \mathrm{g} / \mathrm{mL}$ and $61.50 \mu \mathrm{g} / \mathrm{mL}$ for aspirin and 10 $\mu \mathrm{g} / \mathrm{mL}, 15 \mu \mathrm{g} / \mathrm{mL}, 20 \mu \mathrm{g} / \mathrm{mL}, 25 \mu \mathrm{g} / \mathrm{mL}$ and $30 \mu \mathrm{g} / \mathrm{mL}$ for pravastatin. All the flasks were completed to volume with mobile phase. From these working standard solutions, $20 \mu \mathrm{L}$ portions of each standard solution were injected into the HPLC column. The peak areas of aspirin and pravastatin were determined by following the operating chromatographic conditions. For each drug, the obtained peak areas were correlated to the corresponding concentrations to construct calibration curves. The regression equation was developed.

\section{Analysis of tablets}

For the analysis of aspirin and pravastatin in its pharmaceutical dosage form, twenty tablets were accurately weighed, finely powdered and thoroughly mixed. A quantity of the powdered tablets was precisely weighed so as to contain $41 \mathrm{mg}$ of aspirin and $20 \mathrm{mg}$ of pravastatin. The measured weight was extracted with $50 \mathrm{~mL}$ of mobile phase with the aid of sonication for $10 \mathrm{~min}$. The obtained extract was filtered into a $100 \mathrm{~mL}$ volumetric flask and the volume was completed to mark with mobile phase. The produced tablet extract solution was labeled to contain $410 \mu \mathrm{g} / \mathrm{mL}$ aspirin and $200 \mu \mathrm{g} / \mathrm{mL}$ pravastatin. $5 \mathrm{~mL}$ from the aforementioned extract solution was transferred into $50 \mathrm{~mL}$ volumetric flask to prepare working sample solution (aspirin - 41 $\mathrm{mg}$ and pravastatin - $20 \mathrm{mg}$ ) and the flasks were completed to volume with mobile phase. $20 \mu \mathrm{L}$ of working tablet sample solution was injected into the HPLC system. The peak areas of 
aspirin and pravastatin were determined by following the optimized chromatographic conditions. The concentration of aspirin and pravastatin in tablet was calculated either from the corresponding calibration curve or regression equation.

\section{Degradation studies}

This study was performed by using different $\mathrm{ICH}$ prescribed (acidic, basic, oxidative, thermal and photolytic) stress conditions (Q1A (R2) International Conference on Harmonisation, 2003).

\section{Acid degradation studies}

For acid degradation study, $5 \mathrm{~mL}$ of tablet sample solution $(410 \mu \mathrm{g} / \mathrm{mL}$ aspirin and $200 \mu \mathrm{g} / \mathrm{mL}$ pravastatin) was taken and placed in a $50 \mathrm{~mL}$ volumetric flask. $10 \mathrm{~mL}$ of $0.1 \mathrm{~N} \mathrm{HCl}$ was added to the flask and sonicated for $30 \mathrm{~min}$. After completion of the stress, the solution was neutralized by using $0.1 \mathrm{~N} \mathrm{NaOH}$ and completed up to the mark with mobile phase.

\section{Base degradation studies}

Base degradation study was performed by transferring 5 $\mathrm{mL}$ of tablet sample solution $(410 \mu \mathrm{g} / \mathrm{mL}$ aspirin and $200 \mu \mathrm{g} / \mathrm{mL}$ pravastatin) to a $50 \mathrm{~mL}$ volumetric flask. $10 \mathrm{~mL}$ of $0.1 \mathrm{~N} \mathrm{NaOH}$ was added to the flask and sonicated for $30 \mathrm{~min}$. After completion of the stress, the solution was neutralized by using $0.1 \mathrm{~N} \mathrm{HCl}$ and completed up to the mark with mobile phase.

\section{Oxidative degradation studies}

For this study, $5 \mathrm{~mL}$ of tablet sample solution (410 $\mu \mathrm{g} / \mathrm{mL}$ aspirin and $200 \mu \mathrm{g} / \mathrm{mL}$ pravastatin) was transferred to a $50 \mathrm{~mL}$ volumetric flask followed by addition of $10 \mathrm{~mL}$ of $30 \%$ $\mathrm{H}_{2} \mathrm{O}_{2}$. The contents of the flask were sonicated for $30 \mathrm{~min}$. After completion of stress, the flask was completed up to the mark with mobile phase.

\section{Thermal degradation studies}

The thermal degradation study was performed at $105{ }^{\circ} \mathrm{C}$ for $30 \mathrm{~min}$ in oven. For this study, a quantity of the powdered tablets equivalent to $41 \mathrm{mg}$ aspirin and $20 \mathrm{mg}$ pravastatin was placed in petric disc and exposed to $105{ }^{\circ} \mathrm{C}$ for $30 \mathrm{~min}$ in oven. After the specified time, the tablet powder was cooled and transferred to a $100 \mathrm{~mL}$ volumetric flask containing $50 \mathrm{~mL}$ of mobile phase. After sonication for $10 \mathrm{~min}$, the flask was made up to volume with mobile phase. This solution was diluted appropriately with the same solvent to get a final concentration of $41 \mu \mathrm{g} / \mathrm{mL}$ (aspirin) and $20 \mu \mathrm{g} / \mathrm{mL}$ (pravastatin).

\section{Photolytic degradation studies}

For photolytic degradation, a quantity of the powdered tablets equivalent to $41 \mathrm{mg}$ aspirin and $20 \mathrm{mg}$ pravastatin was placed in petric disc and exposed to sun light for $24 \mathrm{hrs}$. After the specified time, the solution was prepared as described in section 'Thermal degradation studies'. All the stress degraded samples were filtered before injection into the HPLC system. The peak areas of aspirin and pravastatin were recorded from the respective chromatogram.

\section{RESULTS AND DISCUSSION}

\section{Method development}

The study was intended for the effective separation of aspirin, pravastatin and its stress induced degradation products. Various mobile phase combinations of acetonitrile with water, dipotsssium hydrogen phosphate, disodium hydrogen phosphate and glacial acetic acid were investigated to minimize peak tailing, improve peak symmetry, improve column efficiency, improve resolution and minimize total analysis time. Finally a mobile phase consisting of a mixture of water, acetonitrile and glacial acetic acid in the ratio of 40:59:01 $(v / v / v)$ was selected as mobile phase to achieve maximum separation and sensitivity. Different flow rates of mobile phase were studied. A flow rate of $1.5 \mathrm{~mL} / \mathrm{min}$ gave better results. Different temperatures $\left(15^{\circ} \mathrm{C}-35^{\circ} \mathrm{C}\right)$ were evaluated. It was found that the temperature had a negligible influence on resolution and tailing factors. Therefore, room temperature was chosen. Using a reversed phase Phenomex C18 $(200 \times 4.6 \mathrm{~mm}, 5 \mu \mathrm{m})$ column and optimized HPLC conditions (mobile phase combination, flow rate and column temperature), the retention times for aspirin and pravastatin were observed to be $3.654 \mathrm{~min}$ and $4.664 \mathrm{~min}$, respectively. Total time of analysis was $<7 \mathrm{~min}$. The chromatogram at $260 \mathrm{~nm}$ showed a complete resolution of aspirin and pravastatin peaks (Figure 3). The method was validated as per ICH guidelines (International Conference on Harmonization, 2005).

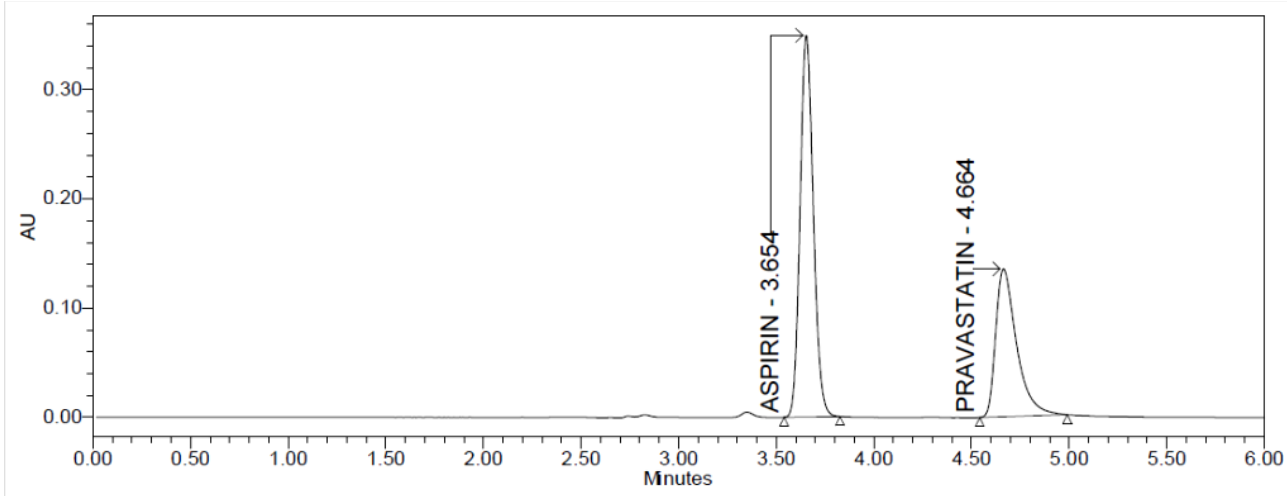

Fig. 3: Typical chromatogram of aspirin and pravastatin Method validation. 


\section{System suitability}

Prior to analysis, the chromatographic system must satisfy system suitability test requirements. The system suitability test was performed by injecting working standard solution containing $41 \mu \mathrm{g} / \mathrm{mL}$ (aspirin) and $20 \mu \mathrm{g} / \mathrm{mL}$ (pravastatin) in five replicates. The percent relative standard deviation (RSD) of the peak area responses and retention times of analytes were determined. Also, USP tailing factor, USP plate count and USP resolution factor were calculated. The results of system suitability in comparison with the required limits are shown in Table 1. The system suitability parameters of the developed method are found to be within the recommended limits.

\section{Linearity}

The linearity of the method was evaluated by analyzing standard solutions of aspirin and pravastatin in the range of 20.5$61.5 \mu \mathrm{g} / \mathrm{mL}$ and $10-30 \mu \mathrm{g} / \mathrm{mL}$, respectively. Calibration curve was constructed by plotting peak area versus concentration of analytes (Figures 4 and 5). The regression equation was calculated. The linear equations for the calibration curves were:

$$
\begin{aligned}
& Y=39148 x+17786, R^{2}=0.9999 \text { for aspirin } \\
& Y=50402 x+944.2, R^{2}=0.9998 \text { for pravastatin }
\end{aligned}
$$

Where $\mathrm{Y}=$ peak area of drug; $x=$ Concentration of drug in $\mu \mathrm{g} / \mathrm{mL}$; $R^{2}=$ regression coefficient

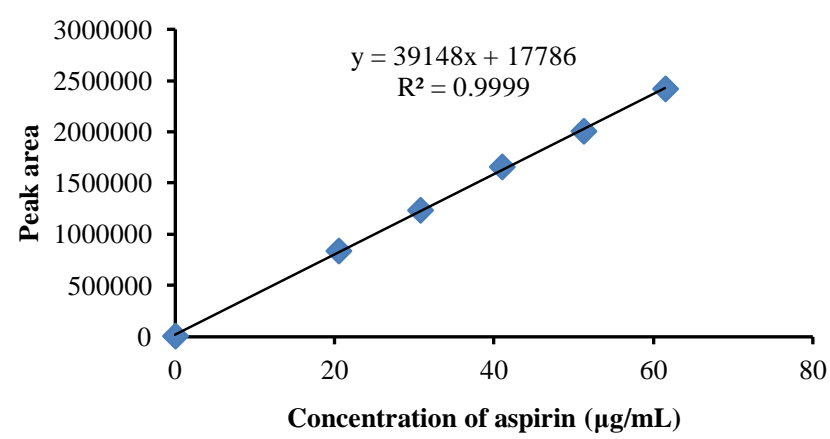

Fig. 4: Aspirin linearity curve.

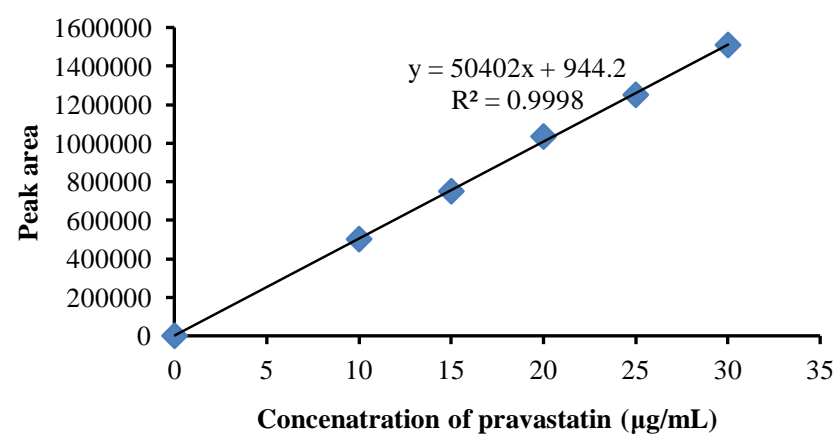

Fig. 5: Pravastatin linearity curve.

\section{Limits of detection (LOD) and quantitation (LOQ)}

LOD and LOQ were calculated as signal-to-noise ratio of $3: 1$ and 10:1, respectively. LOD and LOQ, respectively, were found to be $0.204 \mu \mathrm{g} / \mathrm{mL}$ and $0.680 \mu \mathrm{g} / \mathrm{mL}$ for aspirin and 0.077 $\mu \mathrm{g} / \mathrm{mL}$ and $0.256 \mu \mathrm{g} / \mathrm{mL}$ for pravastatin. The low values of LOD and LOQ indicate the adequate sensitivity of the proposed method.

\section{Selectivity}

The chromatograms of mobile phase blank, placebo blank and tablet sample solution were checked with the standard solution for the appearance of any extra peaks. Placebo blank solution was prepared in the same way of the tablet sample solution by common excipients (starch-40 mg, acacia-30 mg, sodium citrate-35 mg, hydroxyl cellulose-40 mg, magnesium stearate-40 mg, talc-30 mg and sodium alginate-30 mg) of the tablet dosage form but without aspirin and pravastatin. In the chromatogram of tablet sample, single peak for aspirin (retention time-3.653 $\mathrm{min}$ ) and pravastatin (retention time-4.624 min) was obtained under optimized conditions (Figure 6d). The retention times of aspirin and pravastatin in the chromatograms of standard and tablet sample solutions are same (Figures $6 \mathrm{c}$ and $6 \mathrm{~d}$ ). No peaks were observed in the chromatograms of mobile phase blank and placebo blank solutions (Figures $6 \mathrm{a}$ and $6 \mathrm{~b}$ ), showing no interference from common tablet excipients and components of mobile phase.
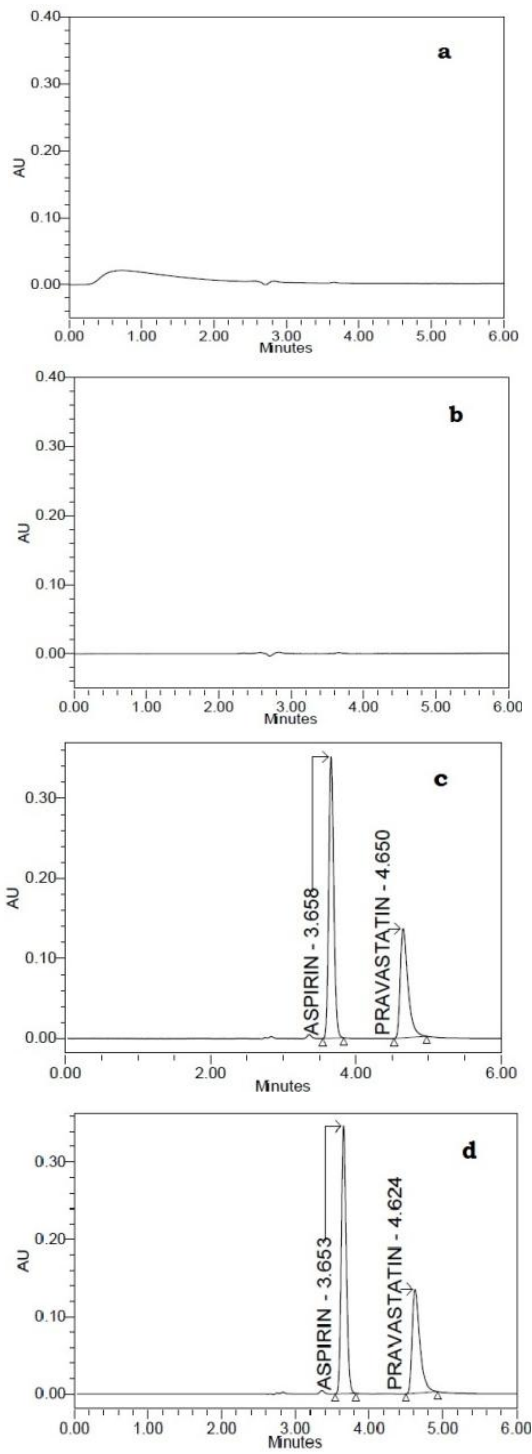

Fig. 6: Chromatogram of [a] Mobile phase blank [b] Placebo blank [c] Standard solution (aspirin $-41 \mu \mathrm{g} / \mathrm{mL}$ and pravastatin-20 mg $\mu \mathrm{g} / \mathrm{mL}$ ) [d] Tablet sample solution (aspirin- $41 \mu \mathrm{g} / \mathrm{mL}$ and pravastatin- $20 \mu \mathrm{g} / \mathrm{mL}$ ) 


\section{Precision}

Precision of the proposed method was studied by making six repeated injections of the standard solution $(41 \mu \mathrm{g} / \mathrm{mL}$-aspirin and $20 \mu \mathrm{g} / \mathrm{mL}$-pravastatin). Relative standard deviation of aspirin and pravastatin peaks was then calculated to represent precision. The relative standard deviation after six determinations was $0.385 \%$ at $41 \mu \mathrm{g} / \mathrm{mL}$ concentration of aspirin and $0.347 \%$ at $20 \mu \mathrm{g} / \mathrm{mL}$ concentration of pravastatin (Table 2 ). The low relative standard deviation $(<0.5 \%)$ values indicate that the developed method is precise.

\section{Accuracy}

Accuracy of the proposed method was established by making six repeated injections of the standard solution $(41 \mu \mathrm{g} / \mathrm{mL}$ aspirin and $20 \mu \mathrm{g} / \mathrm{mL}$-pravastatin). The mean percent recovery of aspirin and pravastatin was calculated to represent the accuracy of the method. The mean percent recovery was $99.58 \%$ for aspirin and $99.16 \%$ for pravastatin (Table 2 ). The high percent recovery values indicate good accuracy of the developed method. The accuracy of the proposed method was further assessed by recovery studies at three different concentration levels by standard addition method. For recovery study, fixed amount of standard aspirin and pravastatin was spiked into preanalyzed sample at three different concentration levels $(50 \%, 100 \%$ and 150\%). The samples were injected into the HPLC system in triplicate and their percent recovery was determined.

The mean percent recoveries obtained for aspirin and pravastatin were in the range of $98.43 \%-100.16 \%$ and $100.06 \%$ $100.81 \%$, respectively (Table 3 ). The results indicated that there was no interference from tablet excipients.

\section{Robustness}

Influence of small changes in chromatographic conditions, such as change in flow rate of the mobile phase $( \pm 0.1 \mathrm{~mL} / \mathrm{min})$ and column temperature $\left( \pm 5^{\circ} \mathrm{C}\right)$, on the method performance was studied to verify the robustness of the developed HPLC method. The method robustness was determined at a concentration of $41 \mu \mathrm{g} / \mathrm{mL}$ and $20 \mu \mathrm{g} / \mathrm{mL}$ of aspirin and pravastatin, respectively. In all deliberately varied chromatographic conditions, the system suitability parameters were found to be well within the acceptable limit (Table 4) indicating the method robustness.

Table 2: Precision and accuracy of the method.

\begin{tabular}{ccccc}
\hline Injection No. & \multicolumn{3}{c}{ Aspirin } & Pravastatin \\
\cline { 2 - 5 } & Peak area & Recovery (\%) & 1001293 & Recovery $(\boldsymbol{\%})$ \\
\hline 1 & 1668363 & 99.92 & 1011739 & 98.68 \\
2 & 1664183 & 99.67 & 1006305 & 99.71 \\
3 & 1664920 & 99.72 & 1003973 & 99.17 \\
4 & 1650119 & 98.83 & 1005997 & 98.94 \\
5 & 1665633 & 99.76 & 1007472 & 99.14 \\
6 & 1662800 & 99.59 & $\mathbf{1 0 0 6 1 3 0}$ & $\mathbf{9 9 . 2 9}$ \\
Mean & $\mathbf{1 6 6 2 6 7 0}$ & $\mathbf{9 9 . 5 8}$ & $\mathbf{0 . 3 4 7}$ & $\mathbf{0 . 3 4 8}$ \\
RSD & $\mathbf{0 . 3 8 5}$ & $\mathbf{0 . 3 8 6}$ & & \\
\hline
\end{tabular}

Table 3: Recovery of aspirin and pravastatin.

\begin{tabular}{|c|c|c|c|c|c|c|c|c|}
\hline \multirow{2}{*}{$\begin{array}{c}\text { Spiked } \\
\text { Level (\%) }\end{array}$} & \multicolumn{2}{|c|}{ Concentration of drug $(\mu \mathrm{g} / \mathrm{mL})$} & \multirow{2}{*}{$\begin{array}{c}\text { Recovery } \\
(\%)\end{array}$} & \multirow[t]{2}{*}{ Mean (\%) } & \multicolumn{2}{|c|}{$\begin{array}{c}\text { Concentration of drug } \\
(\mu \mathrm{g} / \mathrm{mL})\end{array}$} & \multirow[t]{2}{*}{ Recovery (\%) } & \multirow{2}{*}{$\begin{array}{c}\text { Mean } \\
(\%)\end{array}$} \\
\hline & added & found & & & added & found & & \\
\hline \multicolumn{4}{|c|}{ Aspirin } & & \multicolumn{4}{|c|}{ Pravastatin } \\
\hline \multirow{3}{*}{50} & 20.250 & 20.34 & 100.45 & \multirow{3}{*}{100.16} & 9.900 & 9.92 & 100.18 & \multirow{3}{*}{100.26} \\
\hline & 20.250 & 20.29 & 100.21 & & 9.900 & 9.93 & 100.34 & \\
\hline & 20.250 & 20.21 & 99.82 & & 9.900 & 9.93 & 100.27 & \\
\hline \multirow{3}{*}{100} & 40.500 & 39.95 & 98.64 & \multirow{3}{*}{99.14} & 19.800 & 19.76 & 99.79 & \multirow{3}{*}{100.06} \\
\hline & 40.500 & 40.60 & 100.25 & & 19.800 & 19.83 & 100.14 & \\
\hline & 40.500 & 39.90 & 98.53 & & 19.800 & 19.85 & 100.25 & \\
\hline \multirow{3}{*}{150} & 60.171 & 59.81 & 99.40 & \multirow{3}{*}{98.43} & 29.417 & 29.59 & 100.58 & \multirow{3}{*}{100.81} \\
\hline & 60.171 & 59.19 & 98.37 & & 29.417 & 29.63 & 100.72 & \\
\hline & 60.171 & 58.68 & 97.52 & & 29.417 & 29.75 & 101.14 & \\
\hline
\end{tabular}

Table 4: Robustness of the method.

\begin{tabular}{|c|c|c|c|c|c|}
\hline Parameter & Investigated value & Peak Area & USP Plate Count & USP Tailing & USP resolution \\
\hline \multicolumn{6}{|l|}{ Aspirin } \\
\hline \multirow{2}{*}{ Temperature $\left({ }^{\circ} \mathrm{C}\right)$} & $25-2$ & 1839785 & 14233 & 1.17 & - \\
\hline & $25+2$ & 1493451 & 12777 & 1.16 & - \\
\hline \multirow{2}{*}{ Flow rate (mL/min) } & $1.0-0.1$ & 1846468 & 14230 & 1.17 & - \\
\hline & $1.0+0.1$ & 1502076 & 12452 & 1.16 & - \\
\hline \multicolumn{6}{|l|}{ Pravastatin } \\
\hline \multirow{2}{*}{ Temperature $\left({ }^{\circ} \mathrm{C}\right)$} & $25-2$ & 1130638 & 9345 & 1.67 & 5.96 \\
\hline & $25+2$ & 904102 & 8870 & 1.59 & 5.75 \\
\hline \multirow{2}{*}{ Flow rate $(\mathrm{mL} / \mathrm{min})$} & $1.0-0.1$ & 1097569 & 9995 & 1.67 & 6.03 \\
\hline & $1.0+0.1$ & 919782 & 8544 & 1.62 & 5.76 \\
\hline
\end{tabular}




\section{Forced degradation studies/specificity}

The forced degradation study was intended to make sure the effective separation of aspirin, pravastatin and their degradation peaks. Forced degradation studies were performed to assess the stability indicating properties and specificity of the proposed method. Tablet sample solutions for use in stress studies were prepared at a concentration of $41 \mu \mathrm{g} / \mathrm{mL}$ (aspirin) and 20 $\mu \mathrm{g} / \mathrm{mL}$ (pravastatin). Forced degradation study was performed by subjecting the analytes to acid hydrolysis, base hydrolysis, hydrogen peroxide mediated hydrolysis, photolytic and dry heat degradation conditions. The results (percent assay, percent degradation, peak purity angle and purity threshold) of degradation studies are summarized in Table 5. The chromatograms of the degraded samples are shown in Figures 7a-7e. The percentage degradation of aspirin is more in hydrogen peroxide mediated oxidative degradation condition and less in alkali hydrolysis. The pravastatin is degraded more in acid hydrolysis and less in hydrogen peroxide mediated oxidative degradation condition. The determination of the peak purity angle and peak purity threshold values demonstrated that the aspirin and pravastatin peaks were pure in all situations. The stability indicating nature and specificity of the method was demonstrated as no degradation products from different stress conditions affected the detection and quantification of aspirin and pravastatin.

Table 5: Forced degradation studies.

\begin{tabular}{|c|c|c|c|c|c|}
\hline Type of degradation & Peak area & Assay (\%) & Degradation (\%) & Purity Angle & Purity Threshold \\
\hline \multicolumn{6}{|c|}{ Aspirin } \\
\hline Acid & 1534936 & 91.93 & 8.07 & 0.357 & 0.520 \\
\hline Base & 1539578 & 92.21 & 7.79 & 0.347 & 0.528 \\
\hline Oxidative & 1506459 & 90.23 & 9.77 & 0.363 & 0.524 \\
\hline Heat & 1523013 & 91.22 & 8.78 & 0.328 & 0.519 \\
\hline Sunlight & 1511065 & 90.50 & 9.50 & 0.360 & 0.531 \\
\hline \multicolumn{6}{|c|}{ Pravastatin } \\
\hline Acid & 970526 & 95.65 & 4.35 & 0.503 & 0.664 \\
\hline Base & 972016 & 95.79 & 4.21 & 0.479 & 0.657 \\
\hline Oxidative & 992323 & 97.80 & 2.20 & 0.487 & 0.567 \\
\hline Heat & 981560 & 96.73 & 3.27 & 0.484 & 0.660 \\
\hline Sunlight & 985498 & 97.12 & 2.88 & 0.508 & 0.667 \\
\hline
\end{tabular}
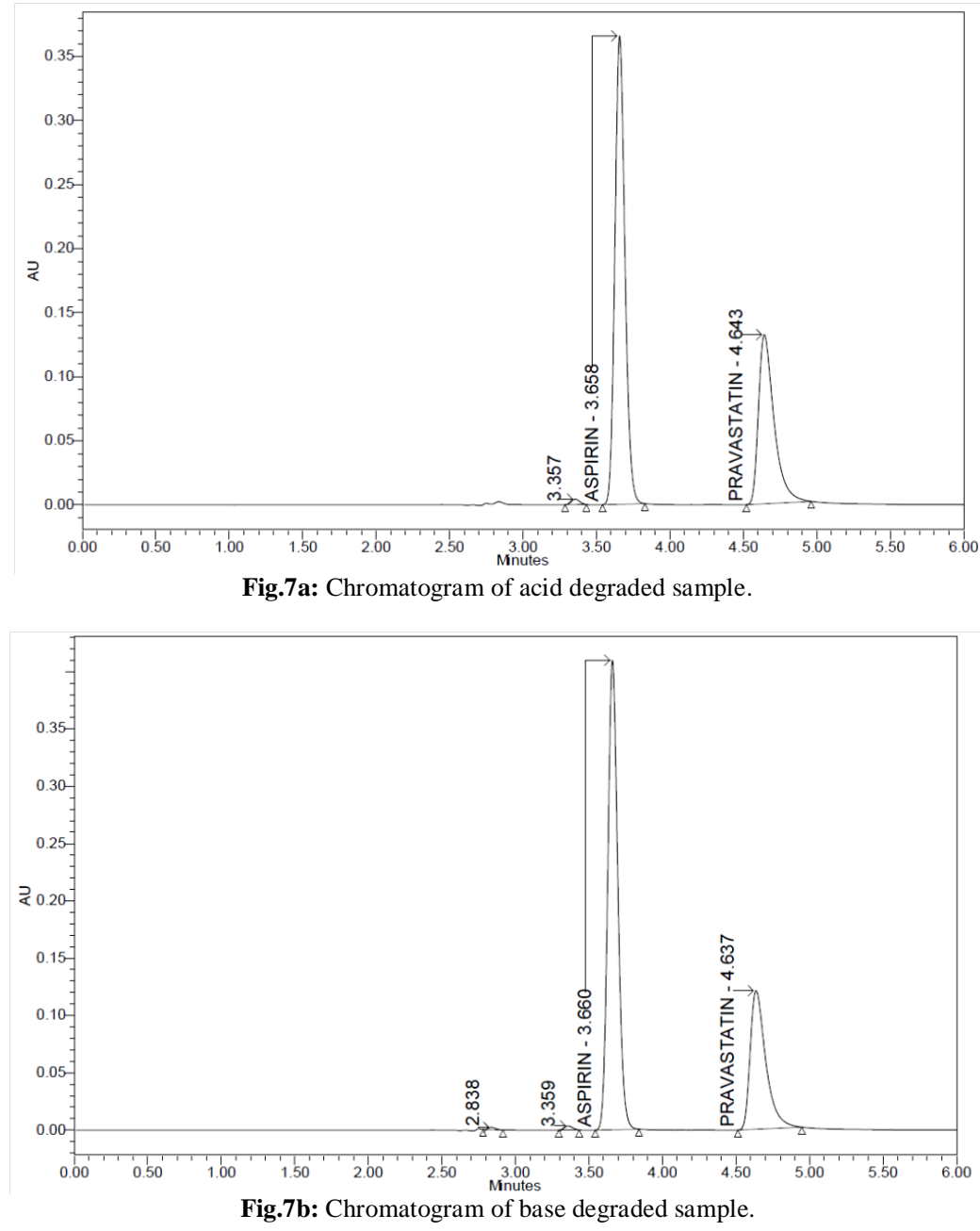


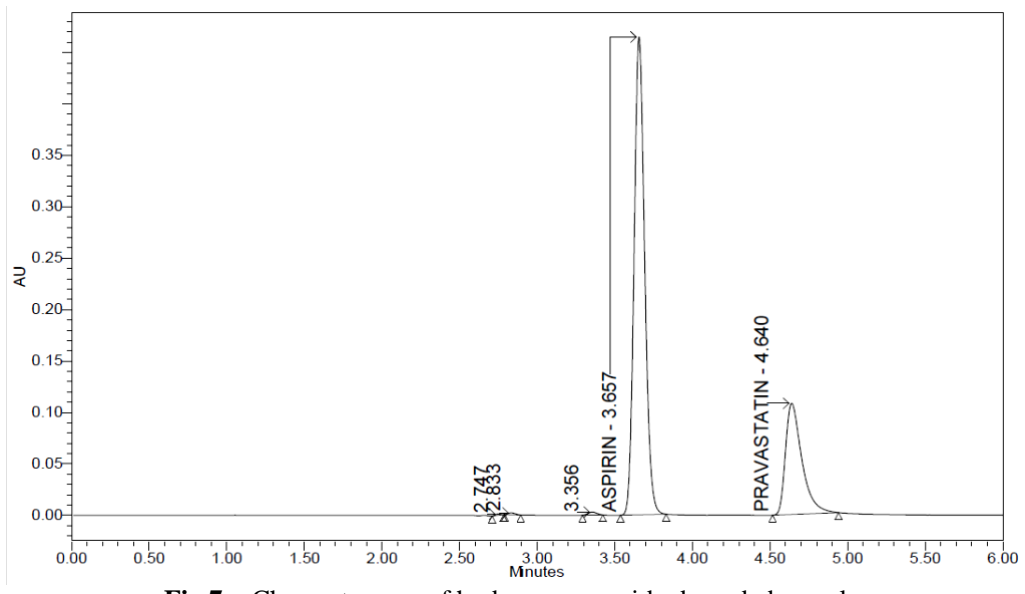

Fig.7c: Chromatogram of hydrogen peroxide degraded sample.
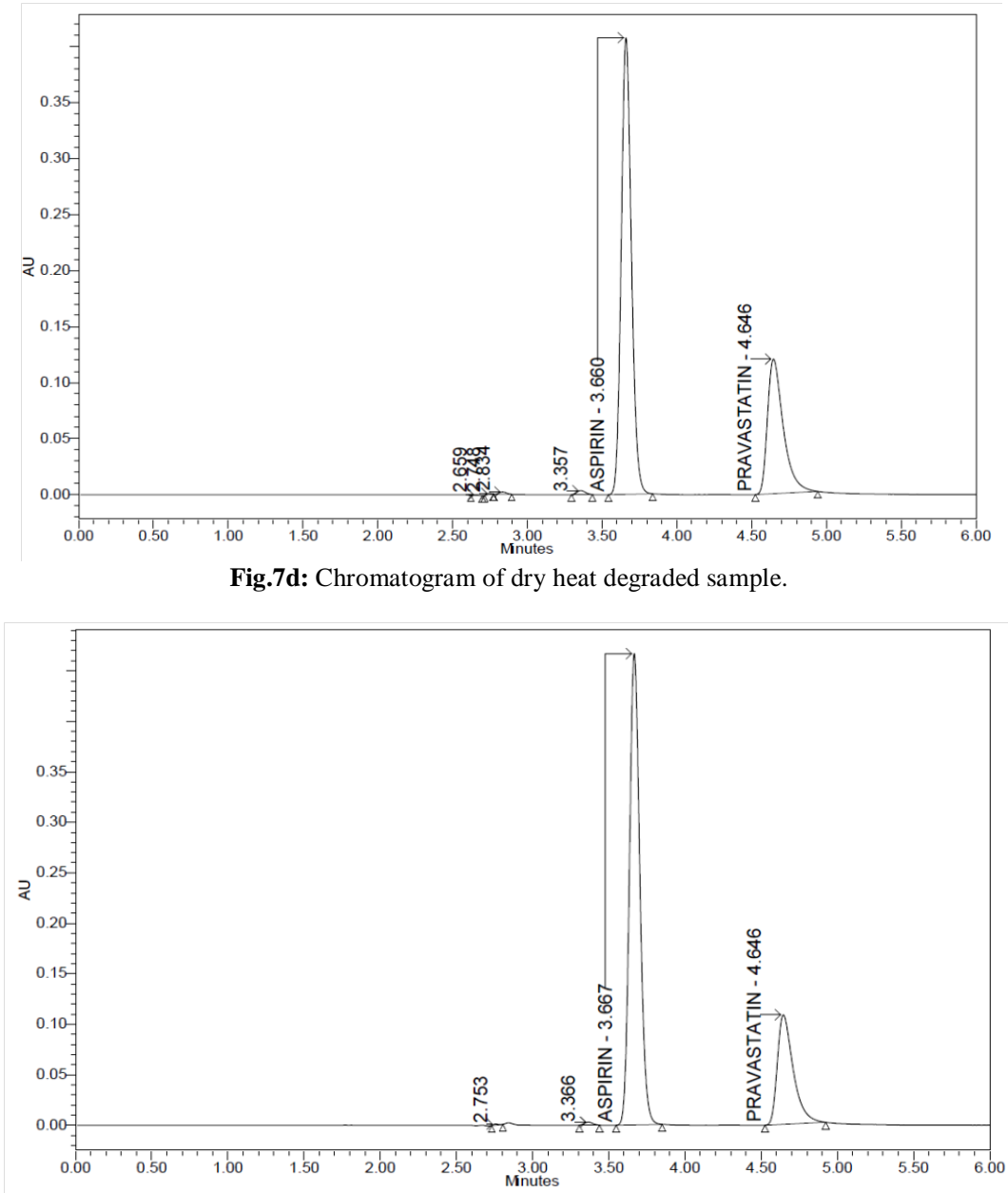

Fig.7e: Chromatogram of photolytic degraded sample.

\section{CONCLUSION}

A simple stability indicating HPLC method with PDA detection for the simultaneous determination of aspirin and pravastatin in bulk and in its pharmaceutical dosage forms has been described for the first time. The proposed method was successfully validated in terms of system suitability, linearity, precision, accuracy, selectivity, specificity, LOD, LOQ and robustness as per the guidelines of ICH. The results of validation parameters were found to be within the acceptable limits. The short run time $(\leq 6 \mathrm{~min})$ make the method suitable for quick and routine analysis. The results of forced degradation studies showed that the proposed method is stability indicating and capable of simultaneous quantification of aspirin and pravastatin in the presence of their degradation products. 


\section{ACKNOWLEDGEMENTS}

The authors are thankful to Prof. K. Ravindra Nath (RPAC Chairman, Department of chemistry, KL University) for giving valuable suggestions in completion of this present work and also to the Rainbow Pharma Training Laboratory, Kukatpally Hyderabad for providing the instruments.

\section{Financial support and sponsorship: Nil.}

Conflict of Interests: There are no conflicts of interest.

\section{REFERENCES}

Akira E. A historical perspective on the discovery of statins. ProcJpnAcadSer B PhysBiolSci, 2010; 86: 484-493.

Andrei AB, Hassan YAE, Fleschin S. FT-IR Spectrophotometric analysis of acetylsalicylic and its pharmaceutical formulations. Can J Anal SciSpectros, 2006; 51:254-259

Bae SK, Seo KA, Jung EJ, Kim HS, Yeo CW, Shon JH, Park KM, Liu KH, Shin JG. Determination of acetylsalicylic acid and its major metabolite, salicylic acid, in human plasma using liquid chromatographytandem mass spectrometry: application to pharmacokinetic study of Astrix in Korean healthy volunteers. Biomed Chromatogr, 2008;22:590-595.

Balaji S, Suman K. Development of spectrophotometric method for determination of pravastatin sodium in bulk and tablet formulation. Int J PharmTech Res, 2009; 1: 1017-1019.

Bauer S, Mwinyi J, Stoeckle A, Gerloff T, Roots I. Quantification of pravastatin in human plasma and urine after solid phase extraction using high performance liquid chromatography with ultraviolet detection. J Chromatogr B AnalytTechnol Biomed Life Sci, 2005; 818:257-262.

Brain-Isasi S, Requena C, Álvarez-Lueje A. Stability study of pravastatin under hydrolytic condition assessed by HPLC. J ChilChemSoc, 2008; 50: 1684-1688.

Ltd., London.

British Pharmacopoeia, 2007a. Her Majesty’s Stationery Office

British Pharmacopoeia, 2007b. Vol. 1 and 2, Her Majesty's Stationery Office Ltd., London.

Charles HH, Frank MS, Andrew T, Jukema JW, Robert PB, Bertram P, Donald AB, Scott MB, Neville FF, Andrew JW, Kannan N, Chen SL, Frederick TF, Rene B. Additive benefits of pravastatin and aspirin to decrease risks of cardiovascular diseaserandomized and observational comparisons of secondary prevention trials and their metaanalyses. Arch Intern Med, 2004;164:40-44.

Codruța C, Ciprian R. Anodic determination of acetylsalicylic acid at a mildly oxidized boron-doped diamond electrode in sodium sulphate medium. Int J Electrochem, 2011; 2011: Article ID 451830, 9 pages.

Enma VPE, John PM, Fadi TK. Aspirin: Pharmacology and clinical applications. Thromb, 2012; 2012: Article ID 173124, 15 pages.

Fernandes JCB, Garcia CAB, Grandin LA, Oliveira N, Graciliano de, Godinho OES. Determination of acetylsalicylic acid in tablets with salicylate ion selective electrode in a batch injection analysis system. J BrazChemSoc, 1998; 9: 249-251.

International Conference on Harmonization, ICH Guidelines, Validation of analytical procedures technical requirements for registration of pharmaceuticals for human use: Text and Methodology Q 2 (R1), International Conference on Harmonization, Geneva, Switzerland, November 2005.

Jane J, Janivishal M. Development and validation of analytical method for pravastatin. ResJ Pharm Tech, 2013; 6: 1116-1120.

Kalvikkarasi S, Vaidhyalingam V, Niraimathi V, Aruna A. Spectrophotometric determination of pravastatin sodium in pharmaceutical oral solid dosage forms. Asian J Chem, 2009; 21: 1648-1650.
Kawabata K, Samata N, Urasaki Y. Quantitative determination of pravastatin and R-416, its main metabolite in human plasma, by liquid chromatography-tandem mass spectrometry. J Chromatogr B AnalytTechnol Biomed Life Sci, 2005; 816:73-79.

Kircali K, Tunçel M, Aboul-Enein HY. Determination of pravastatin in tablets by capillary electrophoresis. Farmaco, 2004; 59:241244

Kokot Z, Burda K. Simultaneous determination of salicylic acid and acetylsalicylic acid in aspirin delayed-release tablet formulations by second-derivative UV spectrophotometry," J Pharm Biomed Anal, 1998; 18: 871-875.

Kumar SS, Jamadar LD, Bhat K, Musmade P, Vasantharaju G, Udupa N. Analytical method development and validation for aspirin. Int $\mathrm{J}$ Chem Tech Res, 2010;2:389-399.

Kunjan BB, Pintu BP, Bhavin PM, Ishwarsinh SR, Shailesh AS. Development and validation of $\mathrm{pH}$ independent spectrophotometric method for determination of pravastatin sodium in dosage forms. J PharmaApplSci, 2014; 1: 23-28.

Lei YH. Spectrophotometric method for the assay of aspirin. ApplMech Mat, 2014; 602-605: 2097-2100.

Luigi C, Valentina M, Mauro T, Stefano V. Quantitative determination of acetylsalicylic acid in commercial drugs using DSC.Comparison with titration and UV spectrophotometric methods. J Therm Anal Calorim, 2010; 102: 249-259.

Majdi S, Jabbari A, Heli H. A study of the electrocatalytic oxidation of aspirin on a nickel hydroxide-modified nickel electrode. J Solid State Electr, 2007; 11: 601-607.

Maruf A, Biswas MHU, Rahman MM, Bhuiyan MSA, Kamal ABHM, Sadik G. Development of a spectrophotometric method for the determination of aspirin in blood sample. J Med Sci, 2001; 1: 61-62.

Moreira AB, Dias ILT, Neto GO, Zagatto EAG, Kubota LT. Solid-phase fluorescence spectroscopy for the determination of acetylsalicylic acid in powdered pharmaceutical samples. Anal ChimActa, 2004; 523: 49-52.

Mulvana D, Jemal M, Pulver SC. Quantitative determination of pravastatin and its biotransformation products in human serum by turbo ion spray LC/MS/MS. J Pharm Biomed Anal. 2000;23:851-866.

Nakamura H, Arakawa K, Itakura H, Kitabatake A, Goto Y, Toyota T, Nakaya N, Nishimoto S, Muranaka M, Yamamoto A, Mizuno K, Ohashi Y. Primary prevention of cardiovascular disease with pravastatin in Japan (MEGA Study): a prospective randomised controlled trial.Lancet, 2006;368:1155-1163.

Nigović B. Electrochemical properties and square wave voltammetric determination of pravastatin. Anal BioanalChem, 2006; 384:431-437.

Nigovic B, Vegar I. Capillary electrophoresis determination of pravastatin and separation of its degradation products. Croat ChemActa, 2008; 81: 615-622.

Önal A, Sagirli O. Development of a selective LC method for the determination of pravastatin sodium. Chromatographia, 2006; 64: 1-6.

Q1 A (R2) International Conference on Harmonization (ICH) of technical requirements for the registration of pharmaceutical for human use stability testing of new drugs substance and products, 2003, pp. 1-18

Raj ND, Kumaravel S, Murugan R, Narayanan SS, Vijayalakshmi R. Reverse phase HPLC method for determination of pravastatin in tablet dosage forms. Int J Res Pharm Sci, 2010; 1: 187-189.

Ramjith US, Sunith DK, Radhakrishnan S, Sameer PA. HPLC study of aspirin and aspirin derivatives. Int J Res PharmaChem, 2013; 3: $1-5$

Rod F. What are all the things that aspirin does?.BMJ, 2003; 327: 572-573

Sahar SM. Comparative analytical study for determination of acetylsalicylic acid in bulk and in pharmaceutical formulations. J AlNahrainUni, 2013; 16: 1-10.

Sallum LF,Soares FLF,ArdilaJA,Carneiro RL. Determination of acetylsalicylic acid in commercial tablets by SERS using silver nanoparticle-coated filter paper. Spectrochim. Acta Mol. Biomol. Spectrosc, 2014; 133: 107-111. 
Sampath K, Ramesh N, Kumar S, Sasijith SL, James DT. Method development and validation of pravastatin sodium in human plasma by using LCMS/MS. J BioequivAvailab, 2011; 3:48-51.

Safwan A, Husni N, Soulafa O. Quantitative determination of pravastatin in pharmaceutical dosage form by HPLC with UV detection. Int J Biomed Sci, 2008; 4: 135-139.

Safwan A, Mouhammed K. Kinetic spectrophotometric determination of pravastatin in drug formulation via derivatization with 4 chloro-7-nitrobenzo-2-oxa-1,3-diazole(NBD-CI). Arabian J Chem, 2011; 4: 299-305.

Sartori ER, Medeiros RA, Rocha-Filho RC, Fatibello-Filho O. Square-wave voltammetric determination of acetylsalicylic acid in pharmaceutical formulations using a boron-doped diamond electrode without the need of previous alkaline hydrolysis step. J BrazChemSoc, 2009; 20: 360-366.

Sekar R, Prasad PR, VairamanM. Determination of acetylsalicylic acid and related substances in pharmaceutical preparations and bulk drugs by capillary electrophoresis. Indian J ChemTechn, 2003; 10: 603-606

Senzana S, Gordana Z, Aleksandra N,Senzana B, Salvinca M.Quantitative analysis of acetylsalicylic acid in commercial pharmaceutical formulations and Human control serum using kinetic spectrophotometry.ActaChemSolv, 2008; 55: 508-515.

Srinivasarao P, Nageswararao P, Venkateswarlu G. High performance liquid chromatography mass spectrometric method for the simultaneous quantification of pravastatin and aspirin in human plasma: Pharmacokinetic application. J Pharm Anal, 2012; 2: 206-213.

The Indian Pharmacopoeia, 2007. Vol. 1-3. The Indian Pharmacopoeia Commission, Ghaziabad.

Toshio K, Kyoichi M, Noriaki N, Yasuo O, Naoko T, Tamio T, Shinichiro U, Haruo N. Pravastatin for cardiovascular event primary prevention in patients with mild-to-moderate hypertension in the management of elevated cholesterol in the primary prevention group of adult Japanese (MEGA) study. Hypertension, 2009; 53: 135-141.
United States Pharmacopoeia/National Formulary, 2000. 24th ed. Pharmacopeial Convention, Rockville, MD.

Vania M. Development, optimization and validation of HPLC method for determination of pravastatin sodium in tablet.Int J AdvPharma Bio Chem, 2014; 3: 230-234.

Valentin F, Joseph MS. Aspirin: A historical and contemporary therapeutic overview. Circulation, 2011; 123: 768-778.

Xu X, Koetzner L, Boulet J, Maselli H, Beyenhof J, Grover G. Rapid and sensitive determination of acetylsalicylic acid and salicylic acid in plasma using liquid chromatography-tandem mass spectrometry: application to pharmacokinetic study. Biomed Chromatogr, 2009; 23:973979.

Zhu Z, Neirinck L. High-performance liquid chromatography coupled with negative ion tandem mass spectrometry for determination of pravastatin in human plasma. J Chromatogr B AnalytTechnol Biomed Life Sci, 2003;783:133-140.

\section{How to cite this article:}

Athota RV, Jagarlapudi SK, Singampalli MR. Stability Indicating Hplc Method for the Simultaneous Quantification of Aspirin and Pravastatin in bulk and Tablets: Method Development and Validation. J App Pharm Sci, 2017; 7 (03): 048-056. 